\title{
DAYA TERIMA DAN KANDUNGAN GIZI (ENERGI, PROTEIN) GYOZA YANG DISUBSTITUSI KEONG SAWAH (PILA AMPULLACEA) DAN PUREE KELOR (MORINGA OLEIFERA)
}

\author{
The Acceptability and Nutrient Content (Energy, Protein) of Gyoza Subtitute \\ with Snail (Pila Ampullacea) and Puree Moringa (Moringa Oleifera) \\ Nabillah Eka Permatasari ${ }^{1^{*}}$, Annis Catur Adi ${ }^{2}$ \\ ${ }^{1}$ Program Studi S1 Ilmu Gizi, Fakultas Kesehatan Masyarakat, Universitas Airlangga, Surabaya \\ ${ }^{2}$ Departemen Gizi Kesehatan, Fakultas Kesehatan Masyarakat, Universitas Airlangga, Surabaya \\ E-mail: nabillaekapermatasari@gmail.com
}

\begin{abstract}
ABSTRAK
Keong sawah dan kelor termasuk bahan makanan yang tinggi akan zat gizi seperti energi, protein, kalsium yang dibutuhkan untuk anak stunting. Penelitian ini bertujuan untuk menganalisis pengaruh substitusi keong sawah (Pila ampullacea) dan puree kelor (Moringa oleifera) terhadap daya terima dan kandungan gizi (energi dan protein) gyoza sebagai jajanan sehat. Penelitian ini menggunakan penelitian eksperimental dengan Rancangan Acak Lengkap (RAL). Panelis pada penelitian ini berjumlah 30 siswa SD kelas V SDN Komplek Kenjeran II 506 sebagai panelis tidak terlatih. Berdasarkan penilaian panelis, formula F3 merupakan formula substitusi terbaik karena unggul dalam aspek warna dan tekstur, namun tidak memiliki perbedaan yang signifikan dalam segi aroma dan rasa bila dibandingkan dengan formula kontrol. Hasil uji statistik Friedman Test menunjukkan terdapat perbedaan yang signifikan pada warna, aroma, tekstur, dan rasa gyoza $(p<0,05)$. Hasil uji lanjut Wilcoxon Signed Rank Test menunjukkan bahwa secara keseluruhan uji beda formula kontrol dan substitusi memiliki perbedaan namun hasil uji antar formula substitusi tidak memiliki perbedaan yang signifikan. Kadar energi dan protein yang dimiliki oleh F3 yaitu sebesar 224,8 g dan 12,75 g/100 g gyoza. Berdasarkan nilai daya terima terbaik dan kandungan gizi tertinggi maka disimpulkan bahwa formula terbaik adalah F3 (75 g keong sawah dan 20 g kelor) sebagai alternatif jajanan sehat untuk anak sekolah.
\end{abstract}

Kata kunci: anak sekolah, gyoza, kelor, keong sawah

\begin{abstract}
Snail and moringa are the example of food that contain several nutrition such as energy, protein, calcium needed by stunted children. The purpose of this study was to analyze the effect of snail (Pila ampullacea) and puree moringa (Moringa oleifera) substitution toward the acceptance and nutritional value (energy and protein) of gyoza as an healthy snack alternative. This study was an experimental with complete random design study. Untrained panelists were 30 students of grade five student in elementary school Komplek Kenjeran II 506. Elementary school Based on scoring by panelist formula F3 is the best treatment formula, because it is better in color and texture aspect but it has no significant difference in aroma and taste compared with treatment formula. The Friedman Test showed there were significant differences in color, aroma, texture and taste $(p<0.05)$. Result of Wilcoxon Signed Rank Test showed that overall test of control formulas and treatment formulas were having differences but the result between treatment formulas were not having significant differences. The highest energy and protein content were F3 $224.8 \mathrm{~g}$ and 12.75 $\mathrm{g} / 100 \mathrm{~g}$ gyoza. Based on the best acceptance value and the highest energy content, it was conclude that the optimization formula was F3 (75 $\mathrm{g}$ snail and $20 \mathrm{~g}$ moringa) as an alternative healthy snack for school-children.
\end{abstract}

Keywords: school-aged children. gyoza, moringa, snail

\section{PENDAHULUAN}

Masalah kesehatan terkait gizi yang sangat rentan terjadi pada anak mulai usia balita hingga usia sekolah diantaranya adalah masalah pendek atau stunting. Stunting didefinisikan sebagai gangguan pertumbuhan yang ditandai dengan adanya kekurangan banyak zat gizi hingga jauh dibawah angka kebutuhan anak dan terjadi secara berulang. Kondisi tersebut dapat ditunjukkan berdasarkan nilai $Z$-score tinggi badan menurut

Nabillah Eka Permatasari, et al., MGI(2018) 62-70

DOI: 10.20473/mgi.v13i1.62-70. 
umur $(\mathrm{TB} / \mathrm{U})$ anak $<-2 \mathrm{SD}$ (Aridiyah, et al., 2015). Menurut Kementrian Kesehatan RI (2013), kejadian stunting diawali dari kejadian underweight atau kekurangan energi kronis yang terjadi secara berkelanjutan sehingga bila tidak segera dilakukan penanganan maka anak akan mengalami stunting, maka dari itu, kecukupan dan peningkatan energi sangat dibutuhkan oleh anak stunting. Kejadian stunting akan berdampak pada performa anak pada masa depan. Kar, et al. (2008) menjelaskan bahwa stunting dapat menurunkan perhatian anak, kemampuan belajar, bekerja, dan kecepatan gerak akan lebih lambat namun kemampuan koordinasi gerak masih menunjukkan performa baik.

Salah satu kelompok yang rentan mengalami masalah kekurangan gizi adalah balita hingga anak usia sekolah dengan rentang usia 7-12 tahun (Sediaoetama, 2000). Anak usia sekolah cenderung lebih banyak menghabiskan waktu di sekolah. Pada masa anak-anak, aktivitas fisik akan lebih meningkat bila dibandingkan masa balita, peningkatan aktivitas fisik akan berdampak pada peningkatan nafsu makan anak, sehingga kecukupan gizi harus terpenuhi secara kuantitas maupun kualitas agar dapat mendukung masa pertumbuhan dan perkembangan anak. Beberapa upaya yang dapat dilakukan untuk memenuhi kebutuhan gizi anak, salah satunya adalah dengan memberikan makanan tambahan berupa jajanan atau snack sehat yang dapat membantu memenuhi kebutuhan gizi anak selama di sekolah, anak-anak juga cenderung menyukai makanan yang manis dan gurih atau asin.

Tren makanan Jepang dan Korea mulai banyak diminati anak, salah satunya adalah gyoza. Gyoza adalah sejenis dimsum hakau yang disajikan dengan dipping sauce, memiliki rasa yang cenderung asin gurih sehingga disukai anak-anak (Kesuma et al., 2015). Selain itu, gyoza merupakan jajanan yang sehat karena mengandung protein, vitamin, dan mineral yang terdapat pada bagian isian, serta energi dan karbohidrat pada bagian kulit gyoza (Permatasari, 2017). Di sisi lain gyoza juga mudah diinovasi, dengan mensubstitusi bahan dasar gyoza dengan bahan pangan lokal yang memiliki nilai gizi tinggi namun jarang digunakan untuk bahan olahan makanan. Orang tua dapat berkreasi membuat makanan anak yang berasal dari bahan pangan lokal dari daerah sekitar tempat tinggal dan diutamakan yang mengandung nilai gizi tinggi yang diolah menjadi makanan siap saji (Permendagri, 2011). Bahan pangan lokal yang berpotensi menjadi bahan substitusi gyoza diantaranya yaitu keong sawah (Pila ampullacea) dan daun kelor (Moringa oleifera) (Permatasari, 2017).

Keong sawah memiliki kandungan gizi yang cukup tinggi. Menurut penelitian Oktasari (2014) keong sawah mengandung $15 \%$ protein, $2,4 \%$ lemak, kadar abu 24\%. Selain itu, keong sawah juga mengandung banyak mineral yang penting untuk tubuh, kandungan mineral tertinggi pada keong sawah adalah kalsium. Keong sawah telah banyak dimanfaatkan sebagai bahan olahan makanan. Penelitian yang dilakukan oleh Tanjung, et al. (2013) menyatakan bahwa pemanfaatan daging tutut (keong sawah) berpotensi untuk dikembangkan menjadi produk bernilai tambah seperti bakso, kripik tutut, kerupuk tutut, sate tutut dan juga dapat dimanfaatkan menjadi alternatif jajanan. Selain itu penelitian yang telah dilakukan Oktasari (2014) menunjukkan bahwa daging keong sawah dapat diolah menjadi nugget sebagai alternatif makanan berprotein tinggi. Sedangkan daun kelor memiliki kandungan gizi yang tinggi antara lain kandungan protein $22,7 \%$, lemak 4,65\%, karbohidrat 7,92\%, dan kalsium 350-50 mg (Nweze et al., 2014). Kandungan asam amino lengkap, antioksidan tinggi, dan antimikroba juga terdapat pada daun kelor segar (Das, et al., 2012).

Berdasarkan pernyataan diatas, perlu adanya penelitian untuk mengetahui pengaruh substitusi keong sawah dan daun kelor melalui penilaian daya terima dan kandungan gizi gyoza sebagai alternatif jajanan sehat anak stunting.

\section{METODE}

Penelitian ini dilakukan dengan dua tahap yaitu tahap pengembangan produk dan uji organoleptik. Pada tahap pengembangan formula jenis penelitian yang digunakan adalah eksperimental murni, dengan rancangan percobaan adalah rancangan acak lengkap (RAL). Penelitian yang dilakukan adalah substitusi keong sawah dan 
Tabel 1. Formula Gyoza Substitusi Keong Sawah dan Puree

\begin{tabular}{|c|c|c|c|c|}
\hline \multirow{2}{*}{ Komposisi (g) } & \multicolumn{4}{|c|}{ Formula } \\
\hline & F0 & F1 & F2 & F3 \\
\hline Tepung terigu & 150 & 125 & 115 & 110 \\
\hline Puree kelor & 0 & 25 & 35 & 40 \\
\hline Daging ayam & 210 & 150 & 90 & 60 \\
\hline Keong sawah & 0 & 60 & 120 & 150 \\
\hline Tepung tapioka & 20 & 20 & 20 & 20 \\
\hline Minyak goreng & 5 & 5 & 5 & 5 \\
\hline Air panas & 65 & 65 & 65 & 65 \\
\hline Wortel & 30 & 30 & 30 & 30 \\
\hline Bawang putih & 20 & 20 & 20 & 20 \\
\hline Saus tiram & 10 & 10 & 10 & 10 \\
\hline Minyak wijen & 10 & 10 & 10 & 10 \\
\hline Garam & 5 & 5 & 5 & 5 \\
\hline Gula & 5 & 5 & 5 & 5 \\
\hline
\end{tabular}

puree kelor pada gyoza menggunakan beberapa formula substitusi yang ditunjukkan pada tabel 1 .

Penelitian dilaksanakan pada bulan Mei -Juli 2017. Proses pembuatan gyoza dilakukan di Laboratorium Pengolahan Fakultas Kesehatan Masyarakat Universitas Airlangga, Sedangkan proses uji laboratorium dilaksanakan di Laboratorium Gizi Fakultas Kesehatan Masyarakat Universitas Airlangga.

Panelis yang akan melakukan penilaian adalah panelis tidak terlatih sebanyak 30 siswa kelas $\mathrm{V}$ SDN Komplek Kenjeran II 506. Panelis tidak terlatih adalah orang awam yang akan menilai sifat organoleptik berupa warna, aroma, tekstur, dan rasa untuk mengetahui tingkat kesukaan terhadap suatu produk. Proses penanganan keong sawah dan daun kelor hingga pembuatan gyoza dijelaskan pada gambar diagram alir 1.

Perhitungan terhadap kadar energi pada penelitian ini menggunakan Tabel Komposisi Pangan Indonesia (TKPI). Penilaian daya terima panelis menggunakan angket uji kesukaan untuk menilai warna, aroma, tekstur, dan rasa produk. Pengolahan data tingkat kesukaan untuk menilai daya terima gyoza dianalisis menggunakan uji Friedman test dan uji lanjut mengggunakan Wilcoxon signed Rank Test. Formula dengan tingkat kesukaan paling tinggi akan di uji kadar energi menggunakan uji proksimat dan kadar protein menggunakan uji Kjeldahl di laboratorium gizi.

Penelitian ini telah lulus uji komite etik dan telah mendapatkan persetujuan berupa sertifikat etik No: 214-KEPK Fakultas Kesehatan Masyarakat Universitas Airlangga.

\section{HASIL DAN PEMBAHASAN}

Uji daya terima panelis tidak terlatih sebanyak 30 siswa kelas V sekolah dasar terhadap tingkat kesukaan warna, aroma, tekstur dan rasa gyoza menunjukkan adanya perbedaan. Perbedaan terjadi karena perlakuan pada setiap formula gyoza memiliki jumlah yang berbeda pada tepung terigu, puree kelor, daging ayam dan keong sawah sehingga dapat memengaruhi karakteristik gyoza. Hasil uji daya terima warna, aroma, tekstur, dan rasa disajikan pada tabel 2. Tabel 2 menunjukkan bahwa F0 yang berupa formula kontrol mendapat penilaian tertinggi dengan nilai mean rank 3,48, yaitu sebesar $56,7 \%$ dari 30 siswa menyukai warna gyoza putih kecokelatan, sedangkan formula substitusi yang mendapat nilai tertinggi adalah F3 dengan nilai rata-rata yaitu 2,25 yaitu sebesar $23,3 \%$ siswa menyukai warna gyoza substitusi hijau kecokelatan. Warna hijau didapatkan karena campuran puree kelor dan kandungan klorofil pada kelor (Krisnadi, 2012).

Hasil uji statistik menggunakan Friedman test menunjukkan nilai $\mathrm{p} \leq 0,005$ sehingga menunjukkan hasil yang signifikan. Selanjutnya uji lanjutan menggunakan Wilcoxon Signed Rank Test menunjukkan terdapat perbedaan antara formula kontrol dan formula substitusi, namun tidak terdapat perbedaan yang signifikan antara formula substitusi. 


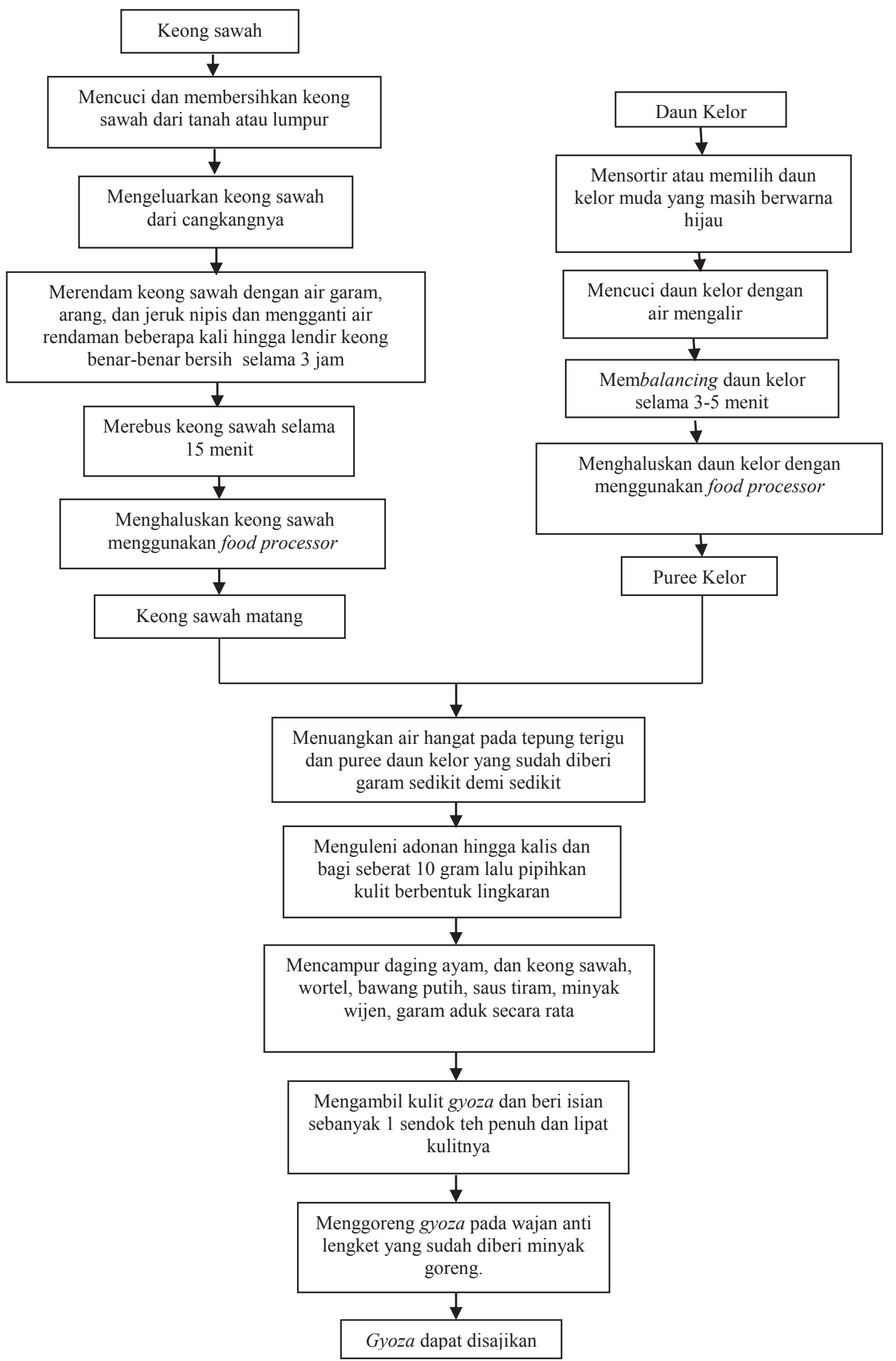

Gambar 1. Diagram Alir Pembuatan Gyoza Subtitusi Keong Sawah dan Daun Kelor 
Aroma suatu produk sangat memengaruhi tingkat kesukaan suatu produk makanan. Winarno (2004) menyatakan bahwa aroma merupakan adanya rangsangan yang ditimbulkan saraf olfaktori dari hidung ketika makanan masuk ke mulut sehingga dapat meningkatkan atau bahkan menurunkan selera makan seseorang. Tabel 2 menunjukkan tingkat kesukaan aroma tertinggi pada formula kontrol $\mathrm{F} 0$ dengan nilai mean rank 3,50 dan sebanyak $56,7 \%$ dari 30 siswa menyukai aroma gyoza yang tidak terlalu tajam, sedangkan aroma formula substitusi tertinggi pada F1 dengan rata-rata $2,27 \%$ dan sebanyak $46,7 \%$ menyukai aroma F1. Hasil uji Friedman test menunjukkan nilai $\mathrm{p} \leq 0,000$. Hasil uji perbedaan aroma dengan menggunakan Wilcoxon Signed Rank Test menunjukkan adanya perbedaan antara formula kontrol dan formula substitusi, sedangkan antar formula substitusi tidak menunjukkan adanya perbedaan aroma. Panelis menyukai aroma gyoza yang tidak terlalu amis. Panelis mengatakan bahwa formula substitusi cenderung memiliki aroma amis walaupun tidak terlalu tajam. Perbedaan aroma tersebut dikarenakan adanya keong sawah pada formula substitusi. Aroma amis keong sawah memerlukan penanganan khusus agar dapat meminimalisir aroma tersebut.
Menurut Darma (2016) cara pengolahan atau pencucian keong sawah yang tepat adalah dengan merendam keong sawah dengan air garam semalaman. Daging keong sawah yang telah dikeluarkan dari cangkang dan dibersihkan dari lumpur direndam di suatu bak dengan air garam dan dapat ditambah dengan daun sirih yang sudah ditumbuk atau jeruk nipis serta jahe yang telah dipotong-potong. Perlakuan keong sawah pada penelitian ini tidak dilakukan perendaman selama semalaman, namun hanya dilakukan selama 3 jam.

Tekstur yang dihasilkan gyoza goreng pada penelitian ini adalah renyah. Secara keseluruhan, tekstur yang dihasilkan pada penelitian ini sama, tekstur renyah ini dihasilkan oleh kulit gyoza, kulit gyoza memiliki tekstur renyah karena menggunakan tepung tapioka dengan perbandingan yang sama. Semua bahan untuk isian gyoza dicampur dan dihaluskan menggunakan food processor sehingga menghasilkan tekstur yang sama.

Tekstur terbaik pada tabel 2 terdapat pada F0 yaitu $40 \%$ dari 30 siswa menyukai tekstur renyah gyoza kontrol, sedangkan gyoza substitusi F1 dan F3 memiliki nilai mean rank hampir sama yaitu 2,45 dan 2,47 dan 46,7\% siswa menyukai tekstur

Tabel 2. Distribusi Tingkat Kesukaan Panelis terhadap Warna Gyoza

\begin{tabular}{|c|c|c|c|c|c|c|c|c|c|c|c|c|}
\hline \multirow{2}{*}{ Karakteristik } & \multicolumn{2}{|c|}{ Sangat tidak suka } & \multicolumn{2}{|c|}{ Tidak suka } & \multicolumn{2}{|c|}{ Suka } & \multicolumn{2}{|c|}{ Sangat suka } & \multicolumn{2}{|c|}{ Total } & \multirow{2}{*}{$\begin{array}{l}\text { Mean } \\
\text { Rank }\end{array}$} & \multirow{2}{*}{ p-value } \\
\hline & $\mathrm{n}$ & $\%$ & $n$ & $\%$ & n & $\%$ & $\mathrm{n}$ & $\%$ & $\mathrm{n}$ & $\%$ & & \\
\hline \multicolumn{13}{|l|}{ Warna } \\
\hline F0 & 1 & 3,3 & 2 & 6,7 & 17 & 56,7 & 10 & 33,3 & 30 & 100 & 3,48 & \multirow{4}{*}{0,000} \\
\hline $\mathrm{F} 1$ & 3 & 10 & 16 & 53,3 & 11 & 36,7 & 0 & 0 & 30 & 100 & 2,13 & \\
\hline $\mathrm{F} 2$ & 3 & 10 & 16 & 53,3 & 9 & 30 & 2 & 6,7 & 30 & 100 & 2,13 & \\
\hline F3 & 5 & 16,7 & 15 & 50 & 3 & 10 & 7 & 23,3 & 30 & 100 & 2,25 & \\
\hline \multicolumn{13}{|l|}{ Aroma } \\
\hline F0 & 0 & 0 & 2 & 6,7 & 17 & 56,7 & 11 & 36,7 & 30 & 100 & 3,50 & \multirow{4}{*}{0,000} \\
\hline $\mathrm{F} 1$ & 4 & 13,3 & 14 & 46,7 & 9 & 30 & 3 & 10 & 30 & 100 & 2,27 & \\
\hline $\mathrm{F} 2$ & 6 & 20 & 15 & 50 & 8 & 26,7 & 1 & 3,3 & 30 & 100 & 2,00 & \\
\hline F3 & 3 & 10 & 18 & 60 & 5 & 16,7 & 4 & 13,3 & 30 & 100 & 2,23 & \\
\hline \multicolumn{13}{|l|}{ Tekstur } \\
\hline F0 & 1 & 3,3 & 12 & 40 & 10 & 33,3 & 7 & 23,3 & 30 & 100 & 2,95 & \multirow{4}{*}{0,030} \\
\hline $\mathrm{F} 1$ & 3 & 10 & 12 & 40 & 13 & 43,3 & 2 & 6,7 & 30 & 100 & 2,45 & \\
\hline $\mathrm{F} 2$ & 5 & 16,7 & 13 & 43,3 & 12 & 40 & 0 & 0 & 30 & 100 & 2,13 & \\
\hline F3 & 2 & 6,7 & 14 & 46,7 & 12 & 40 & 2 & 6,7 & 30 & 100 & 2,47 & \\
\hline \multicolumn{13}{|l|}{ Rasa } \\
\hline F0 & 3 & 10 & 4 & 13,3 & 11 & 36,7 & 12 & 40 & 30 & 100 & 3,18 & \multirow{4}{*}{0,000} \\
\hline $\mathrm{F} 1$ & 8 & 26,7 & 10 & 33,3 & 5 & 16,7 & 7 & 23,3 & 30 & 100 & 2,45 & \\
\hline $\mathrm{F} 2$ & 10 & 33,3 & 12 & 40 & 5 & 16,7 & 3 & 10 & 30 & 100 & 2,02 & \\
\hline F3 & 10 & 33,3 & 8 & 26,7 & 5 & 16,7 & 7 & 23,3 & 30 & 100 & 2,35 & \\
\hline
\end{tabular}




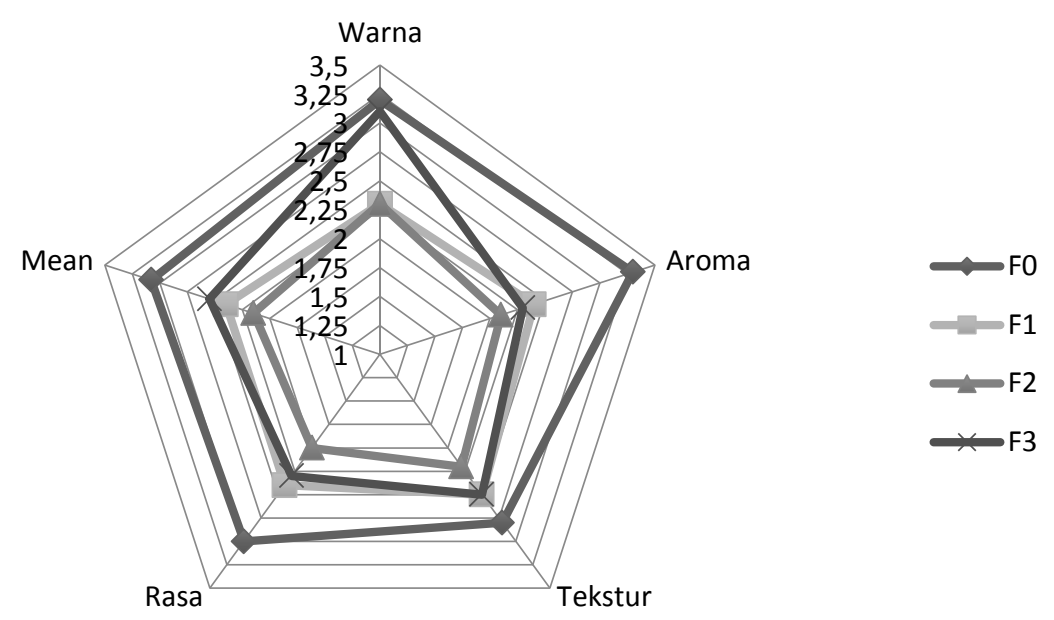

Gambar 2. Tingkat Kesukaan Panelis secara Umum terhadap Gyoza

formula substitusi $\mathrm{F} 3$ dan $43,3 \%$ siswa menyukai tekstur formula substitusi F1.

Tekstur kerenyahan yang sama ini dikarenakan pemberian tepung tapioka dengan komposisi yang sama. Tepung tapioka mengandung amilopektin yang tinggi dan amilopektik berfungsi untuk memberikan efek renyah pada makanan (Niken et al, 2013). Tekstur kerenyahan yang sama ini ditandai dengan hasil pengujian statistik Friedman Test yang menunjukkan tidak ada perbedaan yang signifikan pada tekstur "gyoza" dengan nilai $p$ value $\geq 0,05$.

Rasa yang dihasilkan produk gyoza pada penelitian ini adalah asin cenderung gurih. Rasa asin cenderung gurih dengan aroma wijen yang pekat terdapat pada formula kontrol F0. Pada formula substitusi F1, F2, F3 terdapat sedikit after taste amis karena substitusi keong sawah yang memiliki aroma amis. Sedangkan after taste pahit sendiri dikarenakan proses pemasakan terlalu matang atau gosong (overcook). Tingkat kesukaan ditandai dengan skala 1-4 dari sangat tidak suka hingga sangat suka. Tabel 2 menunjukkan rasa yang paling disukai panelis adalah formula dasar F0 yaitu sebanyak $40 \%$ dari 30 siswa menyukai rasa gyoza formula dasar dengan nilai mean rank 3,18 . Formula substitusi tertinggi terdapat pada formula $\mathrm{F} 1$ dengan $33,3 \%$ siswa menyukai rasa gyoza substitusi, nilai mean rank $\mathrm{F} 1$ menunjukkan nilai 2,45. Hasil uji statistik menunjukkan nilai $p \leq 0,005$ dan uji lanjutan Wilcoxon signed rank test untuk melihat perbedaan dua formula menunjukkan terdapat perbedaan pada formula kontrol dan substitusi sedangkan antar formula substitusi tidak terdapat perbedaan. Pada formula yang mengandung komposisi puree kelor tertinggi terdapat sedikit rasa dan bau langu. Hal tersebut sejalan dengan penelitian Aina, et al. (2014) bahwa semakin banyak penggunaan daun kelor pada suatu produk maka akan semakin kuat rasa daun kelor dan akan menimbulkan rasa dan bau langu. Akan tetapi, pada penelitian ini, penanganan daun kelor telah melalui proses blanching sehingga dapat meminimalisir rasa dan bau langu dari daun kelor (Karyantono, 2016). Hasil uji daya terima gyoza secara keseluruhan ditampilkan pada gambar 2. Hasil uji daya terima gyoza menunjukkan perbedaan yang signifikan pada masing-masing karakteristik (warna, aroma, tekstur, dan rasa) dengan hasil uji ststistik Friedman Test $p \leq 0,05$ pada formula F0 dengan F1, F0 dengan F2, F0 dengan F3. Sedangkan formula substitusi F1, F2, F3 tidak memiliki perbedaan yang signifikan $(p \geq 0,05)$ terhadap daya terima masing-masing karakteristik gyoza. Formula substitusi gyoza yang memiliki daya terima tertinggi adalah formula F3 dengan komposisi tepung terigu sebanyak 110 gram, puree kelor sebanyak 40 gram, daging ayam sebanyak 60 gram, dan keong sawah sebanyak 150 gram.

Daya terima merupakan salah satu penelitian terkait tingkat kesukaan atau ketidaksukaan 
Tabel 3. Distribusi Kadar Energi per 100 gram Gyoza

\begin{tabular}{ccccc}
\hline \multirow{2}{*}{ Formula } & \multicolumn{2}{c}{ Kadar Energi (kkal) } & \multicolumn{2}{c}{ Kadar Protein (gr) } \\
\cline { 2 - 5 } & TKPI & Laboratorium & TKPI & Laboratorium \\
\hline F0 & 264,5 & - & 13,77 & - \\
F1 & 252,6 & - & 13,85 & - \\
F2 & 234,3 & - & 13,13 & 9,93 \\
F3 & 224,8 & 281,2 & 12,75 & \\
\hline
\end{tabular}

(-): tidak dilakukan analisis laboratorium

seseorang terhadap suatu produk makanan (Suhardjo, 2003). Pada penilaian daya terima ini panelis akan mengungkapkan tanggapan pribadinya tentang kesukaan atau ketidaksukaan pada suatu produk makanan dengan menyatakan kesukaannya dari beberapa tingkatan kesukaan seperti sangat suka, suka, netral, tidak suka, sangat tidak suka dan sebagainya, skala penilaian ini juga dikenal dengan skala hedonik (Rahayu, 2001). Berdasarkan gambar 2 dapat disimpulkan bahwa formula substitusi yang memiliki karakteristik hampir sama dengan formula kontrol (F0) adalah formula substitusi F3. Dari keempat karakteristik (warna, aroma, tekstur, dan rasa) formula F3 hampir sama atau mendekati F0, penilaian ini sesuai dengan uji hedonik yang dilakukan panelis. Oleh karena itu dapat dikatakan formula substitusi yang dapat diterima dengan baik oleh panelis adalah formula F3.

Selain penilaian daya terima, penilaian kecukupan gizi khususnya energi dan protein untuk anak stunting juga diperhatikan. Penilaian kecukupan zat gizi anak sekolah disesuaikan dengan Angka Kecukupan Gizi (AKG) dan untuk kebutuhan jajanan anak disesuaikan dengan kebutuhan PMT-AS sesuai anjuran Permendagri tahun 2011. Kebutuhan energi anak sekolah yang harus dipenuhi sekitar 185-307,5 kkal dan kebutuhan protein sebesar 4,9-8,7 gram untuk $10-15 \%$ kebutuhan makanan selingan atau jajanan anak. Angka tersebut sesuai dengan anjuran pemberian PMT-AS.

Kebutuhan energi panelis tidak terlatih yaitu anak SD kelas V usia 10-12 tahun adalah sebesar 205-307,5 kkal sedangkan kebutuhan protein sebesar 5,8-8,7 gram. Hasil perhitungan kandungan gizi dengan menggunakan TKPI (Tabel Komposisi Pangan Indonesia) ditampilkan pada tabel 3.
Tabel 3 memperlihatkan perbandingan kandungan energi dan protein per 100 gram gyoza menggunakan perhitungan TKPI dan hasil uji laboratorium. Berdasarkan data tersebut dapat diketahui bahwa konsumsi 100 gram (4-5 buah) gyoza dapat memenuhi kebutuhan energi makanan selingan (snack) sesuai dengan PMT anak sekolah yaitu sekitar 10-15\% kebutuhan energi setiap hari. Hasil pengujian laboratorium menunjukkan peningkatan hasil perhitungan energi yaitu dari 224,8 kkal menjadi 281,2. kkal Peningkatan ini dapat terjadi karena perhitungan menggunakan laboratorium lebih teliti dan lebih tepat dalam menguji kandungan produk. Perhitungan menggunakan TKPI menggunakan kandungan gizi makanan yang sudah ditetapkan sebelumnya sehingga hasil perhitungan dapat memiliki perubahan antara perhitungan empiris dengan perhitungan laboratorium. Kandungan energi F3 lebih rendah dibandingkan dengan F2, F1, dan F0 karena nilai kandungan energi tepung terigu dan daging ayam berdasarkan TKPI lebih tinggi bila dibandingkan dengan nilai energi kelor dan keong sawah.

Nilai protein pada tabel tersebut menunjukkan kandungan protein tertinggi adalah formula F1. Berdasarkan tabel tersebut konsumsi 100 gram dapat memenuhi kebutuhan protein harian anak sesuai PMT anak sekolah yaitu sekitar 10-15\% kebutuhan harian. Dari tabel tersebut juga terlihat bahwa hasil berdasarkan perhitungan menggunakan TKPI, formula F3 memiliki kandungan protein yang lebih rendah bila dibandingkan dengan F2 dan F1. Hal tersebut dikarenakan kandungan protein pada keong sawah lebih rendah bila dibandingkan dengan kandungan protein ayam. Pada uji laboratorium nilai protein lebih rendah dibandingkan dengan TKPI karena 
adanya pengolahan dengan menggunakan pemanasan (digoreng) pada saat pembuatan gyoza. Penggunaan panas pada pengolahan bahan pangan seperti merebus, mengukus dan menggoreng dapat memengaruhi nilai gizi bahan pangan (Sundari, 2015). Pengolahan bahan pangan yang mengandung protein baik yang melalui proses perebusan, pengukusan, dan penggorengan akan mengalami penurunan tetapi bahan pangan yang digoreng akan mengalami penurunan kandungan protein yang lebih besar dibandingkan bahan pangan segar. Suhu menggoreng mencapai $\pm 160^{\circ} \mathrm{C}$, sehingga sebagian zat gizi diperkirakan akan mengalami kerusakan (Khomsan, 2002).

Penelitian ini masih belum dapat memenuhi kebutuhan energi dan protein anak dikarenakan penggunaan bahan ayam yang memiliki nilai protein dan energi yang lebih tinggi bila dibandingkan dengan keong sawah. Namun menurut penelitian yang dilakukan oleh Permatasari (2017), penggunaan keong sebagai bahan dasar pembuatan gyoza akan menghasilkan nilai ekonomi yang lebih rendah dibandingkan penggunaan ayam, sehingga tepat dijadikan dengan alternatif snack untuk keluarga dari berbagai jenis sosial ekonomi.

\section{KESIMPULAN DAN SARAN}

Produk gyoza substitusi keong sawah dan puree kelor memiliki daya terima yang baik. Formula substitusi terpilih yang paling disukai panelis adalah formula substitusi F3 (keong sawah 75 gram dan puree kelor 20 gram), yang memiliki skor tertinggi pada warna dan tekstur namun tidak memiliki perbedaan yang signifikan dalam aspek aroma dan rasa. Penilaian kandungan gizi formula F3 masih mengalami penurunan melalui penilaian yang dilakukan secara empiris menggunakan tabel TKPI. Walaupun mengalami penurunan, formula F3 masih dapat memenuhi $10-15 \%$ PMT anak sekolah. Dianjurkan konsumsi 100 gram gyoza atau setara dengan 4-5 buah gyoza sebagai makanan selingan agar kebutuhan energi dan protein dapat terpenuhi.

\section{DAFTAR PUSTAKA}

Aina, Q. \& Ismawati, R. (2014). Pengaruh penambahan tepung daun kelor (Moringa oleifera) dan jenis lemak terhadap hasil jadi rich biscuit. Jurnal Mahasiswa Teknologi Pendidikan, 3(3). 106-115.

Aridiyah, F.O, Rohmawati, N, \& Ririanty, M. (2015). Faktor-faktor yang memengaruhi kejadian stunting pada anak balita di wilayah pedesaan dan perkotaan (the factor affecting stunting on toddlers in rural and urban areas). e-Jurnal Pustaka Kesehatan, 3(1).

Cipta. (2014). Sejarah makanan gyoza. Diakses dari http://livejapan.com/id/article/.

Darma, B. (2016). Pengolahan keong mas (kalambuai) dan keong sawah. Diakses dari http://budidarma.com.

Das, A.K, Rajkumar, V, Verna, A.K, \& Swarup, D. (2012). Moringa oleifera leaves extract: A natural antioxidant for retarding lipid peroxidation in cooked goat meat patties. International Journal of Food Science and Technology, 47; 585-591.

Harisina, A.A. (2016). Mutu organoleptik, nilai gizi (protein, kalsium, serat) dan nilai ekonomi flakes substitusi buah sukun (Artocarpus communis) dan kacang hijau (Vigna radiata) (yang tidak dipublikasikan). Surabaya: Universitas Airlangga.

Kar B, Rao S \& Chandramouli B. (2008). Cognitive development in children with chronic protein energy malnutrition. Behavioral and Brain Functions 4, 31.

Karyantono, O. (2016). Kue lepa dengan berbagai formulasi sebagai alternatif makanan tambahan untuk anak sekolah dasar. (yang tidak dipublikasikan) Universitas Airlangga Surabaya.

Kementrian Kesehatan RI. (2013). Laporan Hasil Riset Kesehatan Dasar (Riskesdas). Diakses dari http://www.depkes.go.id.

Kesuma, A, Novayelinda, R. \& Sabrian, F. (2015). Faktor-faktor yang berhubungan dengan perilaku kesulitan makan anak sekolah. e-Jurnal $J O M, 2(2)$.

Khomsan, A. (2002). Susut gizi akibat proses pemasakan. Diakses dari http://www.kompas. com/kesehatan/news/0204/23/015943.htm. 
Krisnadi, A.D. (2012). Kelor super nutrisi. blora (ID): pusat informasi dan pengembangan tanaman kelor Indonesia. Kunduran. Yogyakarta: Lembaga Swadaya Masyarakat Media Peduli Lingkungan (LSM-MEPELING).

Marwoto, R.M, Isnaningsih, N.R, Mujiono, N, \& Alfiah Riena. (2011). Keong air tawar Pulau Jawa (moluska, gastropoda). [PDF] Pusat Penelitian Biologi-LIPI. Tersedia di http://www. lipi.go.id.

Mahmud, M.K, \& Zulfianto, N.A. (2009) Tabel Komposisi Pangan Indonesia (TKPI). Jakarta: Elex Media Komputindo.

Menteri Dalam Negeri Republik Indonesia. (2011). Peraturan Menteri Dalam Negeri Republik Indonesia Nomor 18 Tahun 2011 tentang Pedoman Penyediaan Makanan Tambahan Anak Sekolah. Diakses dari binapemdes. kemendagri.go.id/.../Permendagri_No._18_ Th_._2011_Ttg_.Pedoman_...

Niken, A.H. \& Adepristian D.Y. (2013). Isolasi amilosa dan amilopektin dari pati kentang. Jurnal Teknologi Kimia dan Industri, 2(3). 57-62. Diakses dari http://ejournal-s1.undip. ac.id/index.php/jkti.

Nweze, N.O, \& Nwafor, F.I. (2014). Phytochemical, proximate and mineral composition of leaf extracts of Moringa oleifera lam. Journal of Pharmacy and Biological Science, 9, 99-103.

Oktasari, N. (2014). Pemanfaatan Keong Sawah (Pila amapullacea) pada pembuatan nugget sebagai alternatif makanan berprotein tinggi desa Jurug Kecamatan Mojosongo Kabupaten Boyolali. (Skripsi yang tidak dipublikasikan) Universitas Negeri Semarang. Semarang.

Permatasari, N.E. (2017). Pengaruh substitusi keong sawah (Pila ampullacea) dan puree kelor (Moringa oleifera) terhadap sifat organoleptik, kadar protein, kalsium, zat besi, dan seng serta nilai ekonomi gyoza sebagai jajanan anak sekolah stunting. (Skripsi yang tidak dipublikasikan) Universitas Airlangga, Surabaya, Jawa Timur.

Rahayu, W.P. (2001). Penuntun Praktikum Penilaian Organoleptik. Bogor: IPB.

Sediaoetama, A.D. (2000). Ilmu gizi untuk mahasiswa dan profesi di Indonesia Jilid I. Jakarta: Penerbit Dian Rakyat.

Suhardjo, (2003). Perencanaan pangan dan gizi. Jakarta: Bumi Aksara.

Sundari, D., Almasyhuri., \& Lamid, A. (2015). Pengaruh proses pemasakan terhadap komposisi zat gizi bahan pangan sumber protein. Media Litbangkes, 25(4), 235-242

Tanjung, I.S., Prastiwi, D.A., Nurmaghfiroh., Wulandari, R., \& Kurniawan, E.K. (2013). Bakso tutut: sumber protein baru penggemar bakso. (Laporan akhir program kreativitas mahasiswa) Bogor: IPB.

Wardhono, W. (2012). Pengaruh rasio penggunaan daging tutut dan daging sapi terhadap sensori bakso tutut. (Skripsi yang tidak dipublikasikan). Bandung, Universitas Bandung Raya.

Winarno, F.G. (2004). Kimia pangan dan gizi. Jakarta: Graha Pustaka Ilmu. 